\title{
Action of phosphoric acid on the hydrates of oil of turpentine
}

\section{M.H. Deville}

To cite this article: M.H. Deville (1849) Action of phosphoric acid on the hydrates of oil of turpentine, Philosophical Magazine Series 3, 35:238, 477-478, DOI:

10.1080/14786444908646394

To link to this article: http://dx.doi.org/10.1080/14786444908646394

曲 Published online: 30 Apr 2009.

Submit your article to this journal $\sqsubset \pi$

Џll Article views: 2

Q View related articles $\sqsubset$ 
clusion that it would have the properties of a fatty acid; it boils fixedly at $282^{\circ} \mathrm{Fahr}$; it is volatile without residue.

When oil of turpentine is treated with nitric alcohol, another substance is obtained which may be considered as a liquid hydrate. After remaining mixed for several years, these substances do not dissolve, and the oil of turpentine is not entirely metamorphosed. On heating the viscid and coloured oil which floats on the nitric alcohol to $428^{\circ} \mathrm{Fahr}$, water first comes over, then oil of turpentine, afterwards a peculiar liquid, into the composition of which, judging from the results of analysis, the elements of water enter; it is probably only impure liquid bihydrate of oil of turpentine; it yielded by analysis, -

$$
\begin{aligned}
& \text { Carbon....... 76.4 } \\
& \text { Hydrogen .... 11.6 } \\
& \text { Oxygen ..... 12.0 } \\
& 100 \cdot 0
\end{aligned}
$$

By analogy it ought to be admitted that a liquid terhydrate cannot exist at $292^{\circ} \mathrm{Fahr}$. If it be supposed that an oil be present in this product representing a liquid hydrate, its composition must be,

$$
\begin{aligned}
& \mathrm{C}^{20} \ldots \ldots \ldots 69.8 \\
& \mathrm{H}^{20} \ldots \ldots \ldots 11 \cdot 6 \\
& \mathrm{O}^{4} \ldots \ldots \ldots 18 \cdot 6 \\
& 100 \cdot 0
\end{aligned}
$$

This formula is that of the solid bihydrate of oil of turpentine.

It appears from the above detailed experiments, that oil of turpentine forms with water three very distinct compounds :-

$$
\begin{aligned}
& \mathrm{C}^{20} \mathrm{H}^{16}, \mathrm{H}^{6} \mathrm{O}^{6} \\
& \mathrm{C}^{20} \mathrm{H}^{16}, \mathrm{H}^{4} \mathrm{O}^{4} \\
& \mathrm{C}^{20} \mathrm{H}^{16}, \mathrm{H}^{2} \mathrm{O}^{2} \text { (Blanchet and Sell). }
\end{aligned}
$$

The two first may be converted into each other at pleasure, since a dry vacuum takes away 2 equivalents of water from the terhydrate, and moist air restores 2 equivalents of water to the bihydrate.Ann. de Ch. et de Phys. Septembre 1849.

\section{ACTION OF PHOSPHORIC ACID ON THE HYDRATES OF OIL OF TURPENTINE. BY M. H. DEVILLE.}

When the bihydrate or terhydrate of oil of turpentine is treated with anhydrous phosphoric acid, a colourless oil is obtained, which by distillation is separated into two other oils of different volatility : one is tereben, easily recognized by its odour, fluidity and composition. It gave by analysis-

$$
\begin{aligned}
& \text { Experiment. Calculation. }\left(\mathrm{C}^{20} \mathrm{H}^{16}\right) \\
& \text { Carbon....... 88.1 ....... 88.24 } \\
& \text { Hydrogen. . . . } 11 \cdot 9 \ldots \ldots . .11 \cdot 76 \\
& \overline{100 \cdot 0} \quad \overline{100 \cdot 00}
\end{aligned}
$$

The other oil is viscid, boils at a higher temperature, and is more dense than the above; it possesses characteristic dichroism, sometimes appearing blue and at other times colourless: it is colophen. 
Analysis gave-

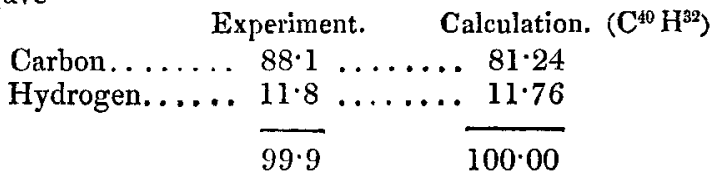

Oil of turpentine acts exactly in the same way with anhydrous phosphoric acid as the hydrates, being like them converted into tereben and colophen.-Ann. de Ch. et de Phys., Septembre 1849.

\section{ON THE INFLUENCE OF BORACIC ACID ON VITRIFICATION.}

M. Maes, manufacturer of flint-glass, has, conjointly with M. Clemandot, long paid attention to the above-named subject. The principal results hitherto obtained are :-1st, borosilicate of potash and lime; 2ndly, borosilicate of potash and zinc; 3rdly, borosilicate of potash and barytes; 4thly, borosilicate of soda and zinc.

The borosilicate of potash and lime was formed with the intention of producing in close vessels with coal furnaces, the best imitations of Bohemian glass. In the Compte Rendu de l'Exposition Autrichienne, 1845, published by $M$. Peligot, it appears, that in order to make the purest and most durable glass in Bohemia, they use with 100 parts of silica, 12 parts of unslaked lime, and only 28 parts of carbonate of potash. From this we must conclude that the glass is better the less potash and the more lime it contains.

The above proportions yield a glass which is infusible in the furnaces employed by $M$. Maes. The addition of a few hundredths of boracic acid is sufficient to occasion fusion, and the resulting product possesses all the limpidity, splendour and hardness which can be desired.

This first experiment naturally suggested the advantage which might be derived from the solvent power of boracic acid so as to introduce bases into glass which had not hitherto been employed, as borosilicate of potash and zinc, and that of potash and barytes. The borosilicate of potash and zinc appeared to impart all the qualities of a pure and durable glass. As to the borosilicate of potash and barytes, it was prepared from native carbonate of barytes, contaminated with sulphate of barytes and a ferruginous gangue. If then it be less colourless than the zinc glass, the colour is certainly accidental : on again making it with pure carbonate, this imperfection would unquestionably disappear.

The beauty of borosilicate of potash and zinc led to the comparative trial of borosilicate of soda and zinc: this, although inferior to the potash, incontestably excelled all the soda glasses compared with it.

To recapitulate : the borosilicates are chiefly remarkable for their transparency and hardness. They derive these important qualitics from reducing considerably the potash and soda which almost always are in excess in common glass; and every one knows that glass which is too alkaline, is cloudy, soft and hygrometric. 